\title{
Leadership succession in politics and business:
}

Converging logics?

\author{
Fredrik Bynander
}

Swedish Defence College

and

Paul ‘t Hart

Utrecht University, Netherlands

Draft chapter for: J.Storey, J.L. Denis, J. Hartley, D. Ullrich and P. 't Hart (eds),

Routledge Companion to Leadership, Routledge 2016

First Draft; Not for Citation

February 2015 


\section{Building them up, cutting them down}

In early February 2015, Australian politics was once again rocked by speculation that a third successive incumbent prime minister was about to be dumped by his own party colleagues. It had happened to Australian Labor Party prime ministers Kevin Rudd (elected November 2007, toppled June 2010) and his replacement Julia Gillard (toppled June 2013). And now Liberal Party prime minister Tony Abbott came perilously close to undergoing the same fate, just fifteen months after having been elected with a large margin by an electorate deeply weary of the unsavory spectacle of three years of factional warfare and political rivalry within the Labor party. Had all these leaders failed so comprehensively so soon as to compel their colleagues to turn off their political oxygen? What were their party room colleagues hoping to achieve in making a leadership change? And why keep going down this road in the face of clear evidence that dumping a leader is a self-defeating strategy for a party keen on winning the next election (Tiffen, 2015)?

One can write this example off as merely another illustration of the irrational nature of politics (or of the substandard quality of the people who land in political leadership roles). But it does not take much to find strong indications that remarkably similar practices of leadership succession occur in the allegedly more rational business world too. Business management scholar Rakesh Khurana (2002) studied patterns of CEO recruitment in large publicly traded U.S. companies and found evidence of a persistent, self-defeating pattern of boards recruiting 'charismatic' CEO's: outsiders to the companies they were brought in to lead, highly self-confident communicators, explicitly tasked with, and bent on, 'shaking up' the place. Hailed as corporate 'saviours' at the point of entry, these new leaders set about frantically slashing costs and reorganizing corporate strategies, structures and business practices. When corporate performance does not improve fast, their momentum stalls as quickly as it was created. The same coalition of forces - investment analysts, institutional investors, recruitment firms, and boards - that brought them in will now dump them, only to surrender 
the leadership of the company to yet another charismatic outsider (Beck and

Wiersema, 2011).

The parallels are striking. In both instances, clever, experienced and selfinterested people authorize and de-authorize leaders in the belief that doing so at the right time and in the right way can change the fate of the organization. In both instances, organizations often claim to embrace 'succession planning', and sometimes devote noticeable preparatory effort to design orderly processes of elite circulation - akin to cooperative 'relay races', as opposed to the competitive 'horse races' (Finkelstein et al, 2009). However, more often than not the practice of succession in both business and political organizations is much more 'messy' and 'political' than that (Bynander and 't Hart, 2008; Frederickson et al, 1988). Clearly in some settings and at least some of the time, the institutional dynamics of leadership selection in politics and business are more similar than one might think. They are certainly a lot more similar than the two virtually completely segmented, self-referential fields of scholarship allow their students and readers to see. By examining both in parallel and showing areas of overlap or potential complementarity, we can enrich leadership studies both theoretically and methodologically. The prize, in short, is to deepen insight into the dynamics of leadership successions in both contexts.

In this chapter, we attempt to build some bridges to cover the chasm. We explore what both disciplines - business studies and political science - have to offer in the way of theory and research about leadership succession. For each, we describe key insights about the causes, processes and outcomes of leadership succession. In the final part of the chapter, we explore similarities and differences and develop propositions for the kind of comparative cross-sectoral research that can serve to energize both fields of research which though quite (political science) and extraordinarily (business studies) active and productive in their distinct ways have also become somewhat stale and predictable.

We use the term leadership succession to denote changes in the occupation of senior positions within political parties (in or out of government) and firms. The 
most conspicuous and consequential successions in politics are those that heads of government and party leaders and in business of CEO's and non-executive board chairs. In politics and business alike, successions can proceed in scheduled (popular elections; term limits) or unscheduled (illness/death; ad-hoc resignations and dismissals) fashion. The initiative to end the term of an incumbent can be voluntary (initiated by the incumbent), consensual (mutual agreement between incumbent and selection bodies) or involuntary (dismissals or forced resignations triggered by a breakdown of confidence among key constituents, moves from competitors and their supporters, public calls for resignation, critical media coverage, or intense legal scrutiny). The selection of a successor can likewise be consensual (succession as a 'relay race') or competitive (a 'horse race', see Bynander and 't Hart, 2006; Finkelstein et al, 2009: 165-68). Business scholars have traditionally focused more on unscheduled CEO departures, whereas political scientists have been equally interested in scheduled (particularly through elections) and unscheduled departures of party leaders.

Perhaps it is good to mention in advance that succession research in both sectors has some key methodological challenges. First, do we conceptualize successions as discrete events or as unfolding processes? The former perspective facilitates straightforward and numerical description of key parameters of these events, their triggers and their outcomes. It allows for large $\mathrm{N}$ studies. The latter encourages a more in-depth mode of analysis that stays closer to the perceptions and decisions of key actors and picks up on the dramatic twists and turns that are part and parcel of many transition and succession episodes. Its requirements limit the scope for large N study, and conduce towards the kind of smaller $\mathrm{N}$ 'focused comparison' (Bennett and George, 2005; Blatter and Haverland, 2013). When does a transition or succession episode begin and end? The eventual resignation and replacement of an office-holder is often the product of a long gestation period, whose origins are not easy to determine unequivocally. And when do new CEO's and party leaders stop being 'new' and become 'settled' incumbents? What time lines for institutionalisation of the new new governance regimes they seek to craft are sensible - and fair - to maintain in assessing their 
'performance' and attribute corporate or party performance to their leadership? Or are we content to simply let public opinion polls and shareholder value serve as proxies?

A second methodological challenge is that of dealing with so-called 'non events'. For every leadership change that is made, there may be a number of aborted attempts to remove the incumbent challenges. In politics, these can be very open: an aspirant 'comes out' and the matter is put to a formal vote. When she is repudiated and the incumbent reconfirmed in the role, are such episodes to be simply written off as non-events, or are they in fact consequential - even necessary - steps in the destruction of the political capital of an incumbent? One needs to know much about the political context of the moment and calculations of the actors involved to be able to answer that question sensibly. Likewise, rumor campaigns in the corporate press or quiet words to board chairs can be thought of as exercises in 'testing the waters' Stakeholder responses allow participants and observers to take stock of potential shifts in the balance of forces in and around the CEO or party leader's 'court'. Such 'non events' impose limits on the ability of traditional large $\mathrm{N}$ dataset studies to fully capture the dynamics of leadership succession. They only emerge on analysts' radars when they really drill down into the inner life of the party/government at the time. So whilst not denying the considerable virtues and practical possibilities of large $\mathrm{N}$ studies in this field, ideally, studies of leadership succession combine large $\mathrm{N}$, events-focused approaches with small N, context-sensitive and process-focused approaches in their overall design.

With these challenges and caveats in mind, let us now examine some of the key findings from each field.

\section{Understanding leadership succession in business}

Business and organizational studies scholars have spent the last 50 years largely focusing on two types of questions. The first looks at the antecedents of succession: how can one explain (changes in) longevity but specifically the 
incidence of 'forced dismissals' of CEO's and other senior executives in firms? Scholars look at the role of both exogenous (industry and market characteristics) and endogenous (ownership, age, corporate governance structures, firm performance, decision-making heuristics) factors to try and explain, and presumably predict, the likelihood of dismissal (Bennedsen et al, 2007; Beck and Wiersema, 2011). Less attention is being paid to other forms of CEO exit, but there is a growing body of work seeking to explain CEO recruitment (Mooney et al, 2007; Graffin et al, 2013).

The other line of research looks at the effects of succession. The central question here is: does changing CEO's and/or senior executive make a difference in firm strategy, behaviour, organizational change and performance (Hutzschenreuter et al, 2012)? There is particular interest in the effects of internally versus externally recruited CEO's - Khurana's (2002) study fits that mould (but see also Agrawal et al., 2006 and Jung, 2014). Also, scholars study the impact of new CEO's on the composition of and relations within the corporate management team as well as with the board (Finkelstein et al, 2009; Barron et al, 2011). Another core issue is the integration between new CEOs and their new organizations (Denis et al. 2000).

Research on CEO succession is overwhelmingly of the large-N variety, drawing on publicly available company and industry statistics, often encompassing decades and including thousands of 'succession events' in their datasets, allowing for sophisticated statistical testing and causal modelling. The volume of research is huge, and there are several major meta-reviews consolidating its findings (Kesner and Sebora, 1994; Finkelstein et al, 2009; Giambatista et al, 2005; Hutzschenreuter et al, 2012). Interestingly, the corporate succession research paradigm has begun to be copied and adapted to examining the dynamics of executive succession in public and non-profit agencies (Boyne and Dahya, 2002; Boyne et al, 2011; Froelich et al, 2011; Teodoro, 2013).

To get a flavour of this sizeable body of work, we concentrate on one of its two key strongholds: the study of the effects of succession. Do new CEO's make a 
difference? The research shows that at some level, they all do: they may change the tone and style of the company's nerve center. They affect the dynamics - and quite often the composition - of the top management team that leads the company. They may forge new relations with the board, investors, shareholders and the business press. They allocate their attention to particular areas of firm performance, push pet projects, and have no or little interest in those of their predecessors. But: does all of this matter, and what for, precisely? It is a question succession researchers wish they could answer, but which to date continues to cause them embarrassment. To their credit, they don't hide the limits of their knowledge. : "Five decades of empirical research (1954-2005) does not, unfortunately, provide much insight... Scholars have failed to reach a consensus on whether succession events in general, and insider vs. outsider successions in particular, affect firm performance positively, negatively, or insignificantly" (Karaevli, 2007: 682). And: “...studies linking CEO succession to organizational performance tend to suffer from a single inescapable fact: organizational performance is a very broad concept and it arises from very complex antecedents" (Finkelstein et al, 2009: 225).

Let us see what they do know. The study of succession impacts on performance has long been dominated by three propositions, emanating from research on coach rotation in sports teams conducted in the 1960s (Grusky, 1963, 1964; Gamson and Scotch, 1964; Rowe et al, 2005). The 'common sense' hypothesis held that the wise choice of a successor, the replacement of a known failure, honeymoon effects accruing to newly appointed coaches and/or managers, and their fresh outlook and zest were likely to induce better performance. Also, in turbulent industries, the competency set of senior executives can be easily outpaced by the swiftly changing rules of the game in the marketplace, at which point a prudent board would find an opportunity to recruit a new, often 'outsider' CEO who provides a better fit (Tushman and Rosenkopf, 1996; Haveman et al, 2001; Finkelstein et al, 2009: 210-1). Other researchers in contrast have suggested that newly appointed executives enjoy all but a honeymoon; rather they are 'extremely vulnerable' in the beginning: being accountable for everything, not having had the time to build up political capital (Frederickson et 
al, 1988: 258) and given a particular, often narrow license to operate by the appointing board (Finkelstein et al, 2009: 202-4). However, these leaders have strategy options available to them to ingratiate themselves with the organization, primarily by "affirmative" or "collaborative" mechanisms, and thus build a platform from which to impose a measure of managerial control of the direction of the organization (Denis et al. 2000: 1093).

The 'vicious circle' hypothesis, in contrast, suggested that teams faring badly are not helped but rather undermined by their frequent rotation of coaches and managers. Each new leader seeks to make their mark under difficult circumstances, which then disrupts routines and lowers morale, hastening further performance decline. Subsequent research beyond the world of sports has shown that the cycle is fuelled by board behaviour rather than CEO behaviour: boards of badly performing companies are more likely to dump their chief executives. They put their new CEO's under bigger pressure to show results fast, who respond to this pressure by pursuing more dramatic, high-risk initiatives, which are more disruptive of the company's existing structures, strategies, culture and practices and for this reason have a higher likelihood of eliciting grief, resistance and uncertainty. When the 'creative destruction' thus pursued does not pay off relatively quickly, the board is more likely to pull the plug than in companies that are in less unforgiving circumstances.

Finally, the 'ritual scapegoating' hypothesis argued that many successions are motivated at least in part to placate frustrated stakeholders and publicly demonstrate awareness of a need for change, but do not lead to any robust performance improvement (or decline). In this way of thinking, CEO resignations and dismissals and presentations of their successors are part of a repertoire of impression management and image repair strategies that have more to do with maintaining and restoring legitimacy than with lifting performance per se (.

Five decades later, the argument is still not settled, despite valiant attempts to integrate the hypotheses into a framework with mediating variables such as the 
timing of executive replacement (Rowe et al, 2005), whether the departing CEO is a founding figure (Carroll, 1984).

It is easy to see why the question of impact is so hard to settle. New CEO's land in existing company governance structures. They inherit the company's existing product mix and production lines, its staff and management, its sales and market shares, its business processes, its cost structure and its profitability. Each of those parameters they can start to influence reasonably directly by their decisions. Or so it seems. In reality, they also inherit the firm's traditions, its (sub)cultures and its reputation. These are crucial mediators of the firm's overall performance, but they are far more opaque and sticky, and in any case take time to transform; time that contemporary CEOs do not necessarily get given by their authorizing environments. In contrast, there is some evidence to support Jim Collins's (2001) contention that successful firms tend to be led by what others have later dubbed 'socialised' CEO's who respect, work with and gently rather than abruptly seek to transform company DNA (Poulin et al, 2007). Whatever their stylistic inclinations and appetite for delivering change, new CEO's will see their ambitions constrained (but also enabled) by the wider context in which the company operates: placid or turbulent market conditions, government regulation and tax regimes, the strategies and strength of competitors.

\section{Assessment and prospects}

An enormous amount of research time and resources have been invested in corporate succession research. Have its results justified the effort? Succession researchers are the first to criticize where the field has come to. For example, at the end of their meta-review, Giambatista et al (2005: 981) observe: 'If the current status of theory in succession literature could be described in one phrase, that phrase would be fragmented and variable" (orig. ital.). They coolly note that no discernible progress has been made in the decade of work - several dozen of studies - they reviewed: “...we are no closer to finding a general theory for either the antecedents leading to leader succession or the impact of leader succession on performance and/or strategic change consequences than we were" (ibid.). They attribute the lack of theoretical convergence to the multidisciplinary nature 
of succession research: scholars from corporate strategy, finance, organizational behaviour and leadership backgrounds each bring their own theoretical baggage, and stick to it. Much succession research is relatively theory-poor, and stuck in the now rather stale 'debate' between the three more than half a century old hypotheses emanating from the sports team studies (Giambatista et al, 2005: 982). To break the stalemate, engagement is needed with broader theories of organizational behaviour, institutionalization, leadership, life-cycles and ecologies (e.g. Ocasio, 1994, 1999; Ocasio and Kim, 1999).

But there is another cause for the relatively modest progress of the field: the bulk of researchers focus on the data they can get rather than they data they should want to have. They study succession 'events' and their 'impacts', but not the processes through which successions come about, new CEO's settle in and try to make their mark. Corporate succession researcher thus largely 'black box' what actually goes on within and between the players involved in succession dramas. They rely on archival information and publicly available succession and performance data. They overwhelmingly eschew the kind of interview, observation and even survey data-gathering methods that could help us open that black box, and produce knowledge that would no doubt be of much greater practical use than the stale and risk-avoiding practical inferences about 'when to make a leadership change' they have produced to date (but see Grunberg, 2002). The field suffers from a rather tragic stand-off: the more hands-on prescriptive books are more often than not largely 'fact-free' in their empirical underpinnings (rooted as they are in story-telling), and the great bulk of empirical studies has little of any relevance to say to those who live in the real world of corporate management. Instead, they have earnestly endeavored to keep compounding evidence for such trite hypotheses as "When organizational performance is poor there will be a greater likelihood of CEO dismissal" (Boeker, 1992: 401). As a result, we learn practically nothing notable about leadership from ploughing through the ever-growing pile of CEO succession studies. Notable exceptions can be found in the small but growing number of social-constructivist, processoriented studies (Haddadj, 2006; Dalpiaz et al, 2014), and rich single-case 
studies that give us a much better insight into the nuances of firm context, firm politics, and the personalities at play (e.g. Lederman, 2007/8).

With such a modest yield, why does this field continue to elicit so much effort? The cynical answer would be that it is a relatively easy game to play: get a research assistant to do the legwork, build the dataset, bring in the advanced statistics, and go for the least publishable unit. Perhaps it is more pertinent to wonder what role path dependencies, imitation, and publication pressures play in sustaining such inward-looking research communities. In any case, it is clear that we will not learn what is really worth noting about corporate succession until its students come out of their self-created shell, and reposition both the theoretical and methodological pillars upon which they have built their subfield. We need less study of succession as its own cause, and more study of succession as part of bigger picture theorizing about organizational behaviour and leadership dynamics. And empirically we need a greater willingness to take risks: more determination to open the corporate 'black box' through use of closeup, 'messy' methods. Fewer numbers, more voices. Less effort to 'explain' in terms of causal modeling and more effort to 'understand' the lived realities and subjective experiences of the leaders who get fired, succeed, and seek to make a difference whilst they are in the chair, as well as of those who put them there and remove them from it.

\section{Understanding leadership succession in politics}

Orderly transfers of power are the litmus test for liberal democracies. Usually, we think of the concession of electoral or parliamentary defeat by a ruling regime and its handing the reins of power to the leader(s) of opposition. Leadership succession deals with the change of leadership within a party or a coalition, which can be a more convoluted process and subject to passions less public but no less intense. An incumbent leader is usually the subject of appreciation as well as jealousy, idolatry as well as contempt. The closest colleagues are the most likely to succeed and rebellion is usually one scandal or poor election result away. 
Political scientists have built datasets or used cross-national comparative designs to study succession in particular types of parties, party systems and polities (democracies and non democracies), or to examine the impact of particular institutional rules and mechanisms of leader succession (Bille, 2001; Kenig, 2009). Examples include Calvert's (1978) early survey, Davis (1998) comparative analysis of six, Cross and Blais (2012) of five, Pilet and Cross (2014) of twelve and Laing and 't Hart (2011) of twenty-three democracies. Beyond that, there are even more comprehensive dataset studies encompassing both democratic and non-democratic polities, such as Bueno de Mesquita et al's (2003) wide-ranging analysis of the institutional, situational, political and behavioural correlates of leader survival in office.

In addition, students of political successions produce intensive 'thick description'-style narrative accounts of succession processes in single cases or focused comparisons across low $\mathrm{N}$ samples. These in-depth, qualitative studies open up the 'black box' of the factional politics that is often at the heart of contested successions. Examples include Punnett (1992), Stark (1996), Denham and O'Hara (2008) and Heppel $(2008,2010)$, all on the UK main parties alone. They also produce theory-driven studies on e.g. the economic and political impact of successions (Bunce, 1981; MacAuley and Carter, 1986), the impact of (changes in) leader selection rules on leader survival, electoral performance and party culture (Weller 1983, 1994; Rahat and Hazan, 2001; Quinn, 2005; 't Hart and Uhr, 2011). Finally, even the 'after-lives' of defeated or retired political leaders have become an object of study (Theakston and De Vries, 2012).

Let us explore what political scientists have found about the triggers, processes and effects of party leader succession. Political leadership is enabled and destroyed by the political capital an incumbent is granted by their authorizing environment: those actors within and outside their parties whose support or at least acquiescence is necessary to prevent rivals from challenging them for the position (Bennister et al. 2014). Motivated leaders with a strong position both in the party and with the potential electorate are hard to unseat and tend to deter 
overt challengers. Laing and 't Hart (2011:122) offer the following typology to characterize the relative strength of an incumbent.

Table 1. A typology of incumbent leaders positions vis-à-vis succession challenges

\begin{tabular}{|l|l|l|l|}
\hline \multirow{2}{*}{$\begin{array}{l}\text { Hold over } \\
\text { own party }\end{array}$} & \multicolumn{3}{|l|}{ Level of external support } \\
\cline { 2 - 4 } & Firm & Strong & Winner (Untouchable) \\
\cline { 2 - 4 } & Weak & $\begin{array}{l}\text { Oligarch (Vulnerable to } \\
\text { changing party support) }\end{array}$ \\
\hline & $\begin{array}{l}\text { Maverick (Vulnerable to } \\
\text { changing public opinion) }\end{array}$ & Loser (Untenable) \\
\hline
\end{tabular}

Source: adapted from Laing \& 't Hart 2011: 122

The first years of leadership are crucial for building up that capital. If leaders manage to survive their first term and/or their first electoral test, their chances for a much longer incumbency increase markedly (Laing \& 't Hart 2011). Leadership capital does tend to erode over time. The wear and tear of leadership forces incumbents to prioritize and make enemies internally as well as externally (Renshon 2000; Bueno de Mesquita et al. 2003; Bennister et al. 2015).

The relative vulnerability of an incumbent is partly a product of institutional factors, particularly the nature of the body that selects them ('selectorate') and its rules of engagement. At one extreme (high vulnerability), parties can hire and fire leaders by means of informal 'inner circles' of party elders or factional power brokers; at the other (low vulnerability), leaders are chosen for fixed terms by secret ballot among all party members. A wealth of research demonstrates the impact of the nature and size of such institutional characteristics as selectorates, term limits and voting rules (Quinn, 2005; Kenig, 2009; Cross and Blais 2012; Pilet and Cross, 2014). The trend in Western democracies has been for the preeminence of the parliamentary parties as selectorates to give way to rank and file member ballots. Posing the leadership question to the rank and file carries risk of jeopardizing the balance of the party fractions. Members from outside the party elite can raise a challenge and force insider candidates into unwanted positions. Once elected by direct member ballot, party leaders don't have to be as meticulously observant of their parliamentary colleagues' needs and views as they must be when the selectorate is e.g. the parliamentary party room. 
Leader vulnerability is however not a static product of institutional structures alone. It can increase at certain moments in the political business cycle: election defeats, internal policy differences on high-stakes issues, 'relegation' to opposition, negative publicity about the leader's performance. Particular succession triggers tend to carry meaning as they play to the strengths and (more often) weaknesses of a leader. For example, when a "maverick" leader suffers a big drop in the opinion polls it deflates her claim of being an electoral magnet, and leaves her less immune from the internal opposition her maverick posture is sure to generate (Costa Lobo 2008). Whispering campaigns commence, challenges are mounted, and even if they are not fully pursued or not immediately won in formal contest, their very existence depletes the incumbent's political capital. A 'vicious cycle' - not dissimilar to that which may take hold of firms and their leaders - of further lackluster performance, rising discontent, and support seeping away can get in motion, and is extremely difficult to break. Sometimes a big external crisis can provide an embattled leader with an opportunity to 'perform authority' (Hajer, 2009) when it is needed most, and thus regain stature. The 2015 Paris attacks did just that for embattled French president Francois Hollande.

The increasingly leader-centric character of modern politics and the advent of marketing and branding techniques in US and European politics have turned leaders into political prize-fighters: core assets for a party in its need to win elections. Entire campaigns are centered on leaders; party brand and personal brand have effectively merged (Lees-Marshment 2012). This has further raised the stakes of leadership selection (Blondel \& Thibault 2009; Karvonen 2010; Calise 2011). Under such a leadership model, the actions of party colleagues, especially when in government, are all attributed to the leader. When the party fails, the natural culprit is thus the leader, who may deflect that blame by firing underperforming associates, reshuffle their top team, or take symbolic remedial action. But they cannot escape the fact that the personalization of politics has come with greater instability at the top (Dowding 2013). 
Party culture is a key factor determining eligibility for leadership. It influences what kind of values leadership candidates should espouse and embody. In essence, the test for a new leader is whether to conform or transform the party's sense of 'who "we" are' (Turner \& Haslam 2001; Subašić \& Reynolds 2011).

One telling example is the revolutionary brand of leadership exercised by Tony Blair as he entered the top job of the British Labour party in 1994 and forged a clean break with a number of party orthodoxies (e.g. the "clause 4" nationalization commitment in the party constitution, and the power of the union movement within the party's institutions) (Minkin 2014; Russel 2005). This was made possible by the eighteen years spent in opposition and the realization that changes touching the core of the party were needed in order to improve the electability of the party.

When an incumbent's weakness becomes clear, a succession episode unfolds. Case study research across a number of parties and epochs has allowed us to draw up a synthetic picture of the process that is set in motion. An incumbent needs to decide, first of all, whether to resist the challenge that is to come, or to throw in the towel. Both these options come with a secondary strategy of resisting change or cooperating with the forces driving a bid for succession (see further Table 2).

Table 2. Incumbent options when faced with a succession trigger

\begin{tabular}{lll}
$\begin{array}{l}\text { a. Deny } \\
\text { exit } \rightarrow\end{array}$ & $\begin{array}{l}\text { (Unconscious) use of psychological defense mechanisms } \\
\text { in order to avoid facing the prospect of impending loss } \\
\text { of office/power }\end{array}$ \\
\hline $\begin{array}{l}\text { b. Resist } \\
\text { exit } \rightarrow\end{array}$ & $\begin{array}{l}\text { Consensus- } \\
\text { seeking }\end{array}$ & $\begin{array}{l}\text { proactive: trying to rebuild political } \\
\text { support by 'trying harder' to 'do better' }\end{array}$ \\
\hline & & $\begin{array}{l}\text { reactive: hoping that succession issue will } \\
\text { blow over ('it's a passing fad') }\end{array}$ \\
\hline & $\begin{array}{l}\text { Conflict- } \\
\text { accepting }\end{array}$ & $\begin{array}{l}\text { proactive: open and covert 'warfare' to } \\
\text { silence critics and eliminate contenders }\end{array}$ \\
\hline & & $\begin{array}{l}\text { reactive: retaliate attacks made by critics } \\
\text { and contender }\end{array}$ \\
\hline c. Accept & Consensus- & proactive: instigating successor selection \\
exit $\rightarrow$ & seeking & process without pushing own candidate \\
\hline & & $\begin{array}{l}\text { reactive: non-interfering in ongoing } \\
\text { successor selection process and accepting } \\
\text { its results }\end{array}$ \\
\hline
\end{tabular}




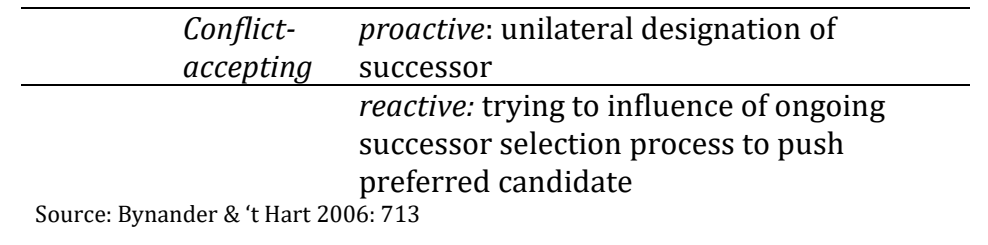

Succession episodes are one-off contests. The context of succession develops and internalizes the strengths and weaknesses of the two or more contenders (Foley 2013). An incumbent's position can be softened up by a farfetched challenge from the fringes of the party that creates expectations of overwhelming victory for the incumbent. Anything short of that will cause serious problems for the leader and make the unlikely contender a lightning rod for internal passions against the incumbent and/or activate other, heavier competition. Restoring a semblance of internal unity now becomes imperative for the incumbent (Ceron 2014). This may require $U$ turns on contentious policies, reshuffling key personnel, or transformation of the party's structure or platform. Successful survivors of serious succession triggers have often been effective in fielding the "better the devil you know" defense. Party organizations generally value stability; appetite for major reform can dwindle quickly in the face of a messy succession battle. The standard incumbency strategy is to keep stability more attractive than change among the power brokers within the party. This may also include the overt or covert threat of retaliation and destabilization of any new leadership that might eventuate (Konrad \& Skaperdas 2007).

The strategic calculus of the incumbent is mirrored by those of the challengers, who initially need to consider whether to field an open contest or wait for the incumbent to be further weakened (see Table 3). The purpose of the latter strategy is not to expose ambition too soon and risk retribution, but also to come across as loyal to a point but ready to accept responsibility. The downside of this strategy is the risk that other contenders will get a head start in staking their leadership claims and that erstwhile internal supporters will see the (potential) candidate as weak and indecisive (Punnett 1992).

Table 3. Challenger options when faced with a succession trigger 


\begin{tabular}{|c|c|c|c|}
\hline \multirow{5}{*}{$\begin{array}{l}\text { Aspiring leader } \\
\text { confronted with } \\
\text { succession } \\
\text { trigger }\end{array}$} & $\begin{array}{l}\text { a. Forego } \\
\text { candidacy }\end{array}$ & & $\rightarrow$ 'nay sayer' \\
\hline & $\begin{array}{l}\text { b. Seek } \\
\text { candidacy }\end{array}$ & $\begin{array}{l}\rightarrow \\
\text { covertly }\end{array}$ & $\begin{array}{l}\rightarrow \text { harmonious posture: } \\
\text { 'spectator' }\end{array}$ \\
\hline & & & $\begin{array}{l}\rightarrow \text { confrontational posture: } \\
\text { 'plotter' }\end{array}$ \\
\hline & & $\begin{array}{l}\rightarrow \\
\text { overtly }\end{array}$ & $\begin{array}{l}\rightarrow \text { harmonious posture: 'crown } \\
\text { prince' }\end{array}$ \\
\hline & & & $\begin{array}{l}\rightarrow \text { confrontational posture: } \\
\text { 'critic' }\end{array}$ \\
\hline \multicolumn{4}{|l|}{$\begin{array}{l}\text { POST- } \\
\text { SUCCESSION }\end{array}$} \\
\hline \multirow{3}{*}{$\begin{array}{l}\text { New leader's } \\
\text { posture vis à vis } \\
\text { departed leader }\end{array}$} & $\begin{array}{l}\text { a. Embrace } \\
\text { heritage }\end{array}$ & & $\rightarrow$ 'heir' \\
\hline & $\begin{array}{l}\text { b. Selective } \\
\text { support for } \\
\text { heritage }\end{array}$ & & $\rightarrow$ 'shopper' \\
\hline & $\begin{array}{l}\text { c. Repudiation } \\
\text { of heritage } \\
\text { rt 2006: } 719\end{array}$ & & $\rightarrow$ 'reformer' \\
\hline
\end{tabular}

The strategic game that then unfolds between incumbent, challengers and secondary stakeholders can take a number of forms. It can be short and sharp or protracted and destabilizing the party for months or more. Core internal and external constituents need to be won. Performance tests - key parliamentary or television appearances, new policy announcements, direct debates - are part and parcel of the vetting and bargaining processes that ultimately determine where the momentum goes. At the tail end of every succession episode is an arduous task for the person left standing: to heal the battle wounds that may have resulted and stake a path that can inject a sense of direction and new credibility for the party. If the new leader does not deliver the new departure with enough vigour and speed, unrest fuelled by resumption of factional hostilities, defections from the new leadership team, and parliamentary rebellions may follow.

For political leaders themselves, the impacts of succession are tangible - their ability to maneuver has a direct relationship to the way in which they were selected and the context in which succession occurred. In effect, the succession process is a primary factor in the mandate that a newly elected (or reconfirmed) 
party leader enjoys. This mandate then needs to be managed in a way that consolidates their position and provides them latitude to design successful election campaigns.

The most straightforward measures of succession impact are leader survival and party (electoral) performance. A key factor determining whether a new leader survives and the party thrives is the level of conflict during the succession process. Research suggests that the connection is counterintuitive (Laing and ' $t$ Hart, 2011). Having triumphed in high-conflict contest with an internal rival (and faction) allows the new leader to exercise a Machiavellian blend of mercy and brutality in a way that realigns internal loyalties and creates a new mandate. Low-conflict succession leaders on the other hand have to some extent tied themselves to the mast by accepting a scenario endorsed by the existing dominant coalition, which may not break the downward electoral spiral that triggered the succession in the first place.

\section{Assessment and prospects}

There are still blind spots in the study of party leadership succession. What we know about political systems, political culture and party structures isn't always lining up with what we need to shed more light on leadership succession. More integration between the subfields that explore these complex areas is needed if there is to be major inroads into the understanding of the significance and impacts of different modes of leadership succession (Foley 2013). As political leadership succession analysis comes of age it needs to nurture the budding comparative perspective, integrate with other more established fields of leadership studies, and develop the scope and boundary conditions for its explanatory ambitions. During the last decade, the field has proposed and tested generalizations about when, why, and how successions occur, and what effects they may have on the key protagonists' careers, the performance of the party, and the policies it pursues. We believe that the methodological diversity that it has come to display is part of the strength of this subfield. There is a nascent interplay between the in-depth and the large- $\mathrm{N}$, the causal and the interpretive, the bird's eye view and the down in the dirt view. Such diversity and multi- 
method approaches need to be nurtured. It is now time to switch the focus of recent times - the impact of changing rules for leader selection on leader legitimacy and longevity - towards the next horizon: examining the implications of the weakening of established cadre parties with 'democratised' rules for leader (de)selection and the rise of a new wave of movement parties of the populist, proto-charismatic variety whose entrepreneurial founder-leaders are less constrained by internal checks and balances (Mair, 2013).

\section{Towards convergence}

It has long been customary to treat the corporate and political sectors as distant universes, and therefore business and political leadership as entirely different crafts. But today it is easy to overstate those differences. Small and mediumsized firms, large corporations, political parties and governments are all facing the same set of megatrends that challenge their common roots as modernist projects of instrumental rationality through order, design, control and hierarchy. These trends include: accelerating and disruptive technological change; globalization and connectivity of markets, social problems and governance structures; greater public demand for transparency and accountability from any type of entity, profession or authority figure whose actions affect their lives; mass media, social media and mobile devices permanently shaping people's cognitive and emotional frames, creating web-empowered customers and citizens with 'liquid' tastes, preferences, values and life styles ('t Hart, 2014). The world in which business and political leaders operate has become 'flat': demanding, changeable, boundary-less, fast-paced. They feel the pinch: their longevity in office has gone down while the percentage of forced departures has gone up. Business and political leaders thus face a similar paradox: satisfying a romantic longing for 'charismatic' leadership that provides protection, direction and order in a complex and volatile world where nothing can be taken for granted anymore, and at the same time being constrained in exercising that leadership by a thickening of governance structures and accountability requirements that enable their authorizing environment to contain them and get rid of them more effectively. There is appetite for transformational leadership, 
yet the dominant rules of the game governing both business and political leadership conduce towards transactional leadership (cf. Burns, 1978).

Given this unfolding institutional isomorphism, what might be some productive lines for comparative, cross-sectoral inquiry? We propose three theoretical points of departure that could inspire such work. These are paths to distinct but mutually reinforcing understandings of what makes leaders effective in running their organizations. In order to do the job, they need to retain a measure of control, be able to stick around long enough to make a difference, and lastly to leave at such as time and in such a manner so as to provide their successors with a fair shot at continuing to develop the organization in a sustainable direction.

Our choice of theoretical departure has methodological consequences. The richness reported in this study suggests that in order to advance leadership succession studies, multi-method approaches are necessary, not only to be able to pose relevant questions and reach viable conclusions, but also to be able to foster cross-fertilisation between researchers that to a large degree have been operating on starkly different conceptual and methodological canvases. .By 'mixing and mashing' both concepts, propositions and research design we may be to convince scholars from both niche fields in business studies and political science that there is added value in taking notice of and utilizing what the others are doing. It will a require a sustained effort to birth and consolidates a more integrated field of leadership succession analysis, but here are some questions that could be at its core:

Firstly, from a power perspective on succession, the lens can be turned on the question of who controls whom. A power perspective on political succession invites us to analyze successions as products of strategic and tactical choices, as well signalling, impression management, and bargaining. It sees the rise, tenure, actions, impact and departure of leaders in terms of the ongoing pulling and hauling between leaders and those who can select, empower, de-authorize and remove them within the relevant governance structure. Political scientists should take note of the elite circulation versus institutionalisation of power 
models that have been used and refined in the study of CEO dismissals (Ocasio, 1994). Likewise, the 'power game' of incumbent-challenger(s) interaction as modelled by Bynander and 't Hart $(2006,2008)$ might inspire students of corporate successions to go beyond penetrating the succession politics within firms more effectively. Likewise, Finkelstein et al's (2009) synopsis of the big body of work on the politics of top management teams can be usefully fused with Dowding et al's (2013) work on the politics of ministerial survival and cabinet reshuffles to provide an integrative perspective on the power dynamics that produce both corporate and political successions and influence their outcomes.

Secondly, an accountability perspective on succession generates a set of related, but analytically distinct set of questions (Mulgan, 2003; Uhr, 2005). Which mechanisms are in place to ensure that CEO's and party leaders, who are put there to act as 'agents' on behalf of some constituency and/or set of values and interests, are induced to render account of their behaviour to the 'principals' who put them there? Who are in effect the relevant principals for, say, party leaders, cabinet ministers or departmental secretaries, and how are the accountability relationships between principals and agents constituted? The many instances of change to party rules of leadership selection and removal that we have seen across the democratic world in the last three decades have in large part been motivated by the idea of opening these pivotal leadership processes up to broader scrutiny and indeed participation, even down to the level of ordinary party members. Likewise, the thickening of corporate governance structures has aimed to strengthen the checks and balances around corporate executives. A key question generated by the accountability perspective on succession is to what extent these aims have been realised, and succession episodes are good place to conduct such inquiry. What can the course and outcomes of succession episodes teach us about the real terms of the principal-agent relationships between owners, shareholders, boards and CEO's within corporations, and between party members, auxiliary organizations, parliamentarians and party leaders within political parties? 
This leads into a third area of comparative inquiry, guided by a normative perspective on succession. How do we know a 'good', 'well-managed' succession if we see it? The academic literature has been largely silent on this, preoccupied as it has been with the when, how and why-questions that suit its empirical toolkit. But as a result, it has left the job of assessing and advising about successions to the largely theory-deprived and 'fact-free' world of self-help succession planning guides (e.g. Rothwell, 2010). There is no normative theory of succession, but should there be? What ought to be the values that parties and companies seek to maximize when they design their leadership succession rules, and when key actors within both consider replacing incumbent senior officeholders? How to institutionalize succession norms and practices that effectively navigate the tension between the need for continuity and predictability of corporate, party and government strategy with the need for responsiveness to electoral or market signals, new leaders' need for distinctive political capital and indeed the need for periodic 'creative destruction' and course changes in the life of institutions? At a minimum, we would want key decisions about leader selection and removal to be taken in a transparent, inclusive fashion. More ambitiously, successions should select office-holders in such a manner as to have the authority necessary for not just surviving in the role but actually exercising leadership. These are just ruminations of course. What we need is a field of research that does not eschew but embraces the challenges of evaluating successions. This would provide it with the much needed impetus to transform itself from what to date have been largely two sets of uncoordinated academic parlour games into a more ambitious and more relevant endeavour that is both transdisciplinary and applied.

\section{References}

Barron, J.M., Chulkov, D.V., Waddell, G.R. (2011), Top management team turnover, CEO succession type, and strategic change. Journal of Business Research 64(6): 904910

Bennedsen, M., Nielsen, K.M., Perez-Gonzalez, F., Wolfenzon, D. (2007). Inside the Family Firm: The Role of Families in Succession Decisions and Performance. The Quarterly Journal of Economics 122 (2): 647-691 
Bennett, A., George, A.L. (2005) Case Studies and Theory Development in the Social Sciences, Cambridge: MIT Press

Bennister, M., 't Hart, P., Worthy, B. (2015) Assessing the authority of political office-holders: The Leadership Capital Index. West European Politics, 38(3): 417-440

Bille, L. (2001) 'Democratizing a democratic procedure: myth or reality? Candidate selection in Western European parties, 1960-1990', Party Politics, 7(3), 363-80

Blatter, J., Haverland, M. (2013) Designing Case Studies: Explanatory Approaches in Small-N Research, Basingstoke: Palgrave

Boeker, W. (1992), Power and managerial dismissal: Scapegoating at the top. Administrative Science Quarterly 37 (3): 400-421

Boyne, G. and Dahya, J. (2002) 'Executive succession and the performance of public organizations', Public Administration, 80(1), 179-200

Boyne G. A., James O., John P. and Petrovsky N. (2011) Top management turnover and organizational performance: A test of a contingency model. Public Administration Review 71(4): 572-581

Bueno de Mesquita, B., Smith, A., Siverson, R. M., and Morrow, J. D. (2003) The Logic of Political Survival. Cambridge, Mass.: MIT Press

Bunce, V. (1981) Do New Leaders Make a Difference? Executive Succession and Public Policy Under Capitalism and Socialism. Princeton: Princeton University Press

Burns, J.M. (1978) Leadership. New York: Harper and Row.

Bynander, F., 't Hart, P. (2006) When power changes hands: The political psychology of leadership succession in democracies, Political Psychology 27(5): 707-729

Bynander, F., 't Hart, P. (2008) The art of handing over: (Mis)managing party leader successions. Government and Opposition 43(2): 385-404

Calise, M. (2011) Personalization of politics. In: B. Badie (ed.) International Encyclopedia of Political Science. Thousand Oaks: Sage.

Calvert, P. (ed.)(1978) The Process of Political Succession. Houndmills: Macmillan

Carroll, G.R. (1984) The dynamics of publisher succession in newspaper organizations. Administrative Science Quarterly 16(3): 416-428

Ceron, A. (2014) Inter-factional conflicts and government formation: Do party leaders sort out ideological heterogeneity? Party Politics, published online on December 16, 2014.

Collins, J. (2001) Good to Great. New York: Harper 
Costa Lobo, M. (2008) Parties and leader effects: Impact of leaders in the vote for different types of parties. Party Politics 14(3): 281-298

Cross, W., \& Blais, A. (2012a) Who selects the party leader? Party Politics 18(2): 127-150

Cross, W., Blais, A. (2012b) Politics at the Centre. The Selection and Removal of Party Leaders in the Anglo Parliamentary Democracies. Oxford: Oxford University Press

Dalpiaz, E., Tracey, P., Phillips, N. (2014), Succession narratives in family business: The case of Alessi, Entrepreneurship Theory and Practice, 38: 1375-93

Davis, J. W. (1998) Leadership Selection in Six Western Democracies. Westport: Greenwood Press

Denham, A., O'Hara, K. (2008) Demcratising Conservative Leadership Selection: From Grey Suits to Grass Roots. Manchester: Manchester University Press

Denis, J-L., Langley, A., Pineault, M. (2000) Becoming a Leader in a Complex Organization. Journal of Management Studies, 37(8): 1063-1100.

Dowding, K. (2013) Prime-ministerial power: Institutional and personal factors. In: P. Strangio, P.'t Hart, and J. Walter (eds) Understanding Prime Ministerial Performance: Comparative Perspectives. Oxford: Oxford University Press.

Dowding, K., Berlinski, S. Dewan, T. (2012) Accounting for Ministers: Scandal and Survival in British Government, 1945-2007. Cambridge: Cambridge University Press

Finkelstein, S., Hambrick, D.C., Cannella, A.A. (2009) Strategic Leadership: Theory and Research on Executives, Top Management Teams, and Boards. Oxford: Oxford University Press

Foley, M. (2013) Political Leadership: Themes, Contexts, and Critiques. Oxford: Oxford University Press.

Frederickson, J.W., Hambrick, D.C., Baumrin, S. (1988) A model of CEO dismissal. The Academy of Management Review 13(2): 255-270.

Froelich, K., McKee, G., Rathge, R. (2011) Succession planning in non profit organizations. Nonprofit Management and Leadership 22(1): 3-20

Gamson, W.A., Scotch, N.A. (1964) Scapegoating in baseball. American Journal of Sociology 70(1): 69-72

Giambatista, R.C., Rowe, W.G., Riaz, S. (2005), Nothing succeeds like succession: A critical review of leader succession literature since 1994. The Leadership Quarterly 16(5): 963-991

Grunberg, J. (2002) Problematic Departures: CEO Exits in Large Swedish Publicly 
Traded Corporations. Doctoral Thesis no. 93. Uppsala: Department of Business Studies

Grusky, O. (1963) Managerial succession and organizational effectiveness. American Journal of Sociology 69(1): 21-31

Grusky, O. (1964) Reply to scapegoating in baseball. American Journal of Sociology 70(1): $72-76$

Haddadj, S. (2006) Paradoxical process in the organizational change of the CEO succession. Journal of Organizational Change Management 19(4): 447 - 456

Hajer, M. (2009) Authoritative Governance. Oxford: Oxford University Press

Haveman, H.A., Russo, M.V., Meyer, A.D. (2001) Organizational environments in flux: The impact of regulatory punctuations on organizational domains, CEO succession and performance. Organization Science 12(3): 253-73

Heppell, T. (2008) Choosing the Tory Leader: Conservative Party Leadership Elections from Heath to Cameron. London: Taurus

Heppell, T. (2010) Choosing the Labour Leader: Labour Party Leadership elections from Wilson to Brown. London: Taurus

Hutzschenreuter, T., Kleindienst, I., Greger, C. (2012), How new leaders affect strategic change following a succession event: A critical review of the literature. The Leadership Quarterly 23(4): 729-755

Jung, J. (2014) Political contestation at the top: Politics of outsider succession at U.S. corporations. Organization Studies 35(5): 727-764

Karaevli, A. (2007) Performance Consequences of New CEO 'Outsiderness':

Moderating Effects of Pre- and Post-Succession Contexts. Strategic Management Journal 28(7): 681-706

Karvonen, L. (2010) The Personalisation of Politics: A Study of Parliamentary Democracies. Colchester: ECPR Press.

Kenig, O. (2009) Democratization of party leadership selection: Do wider selectorates produce more competitive contests? Electoral Studies 28(2): 240-47

Kesner, I. F., \& Sebora, T. C. (1994) Executive succession: Past, present and future. Journal of Management (20)2: 327-372

Khurana, R. (2002) Searching for a Corporate Savior: The Irrational Quest for Charismatic CEO's. Princeton: Princeton University Press

Konrad, K. A., \& Skaperdas, S. (2007) Succession rules and leadership rents. The Journal of Conflict Resolution 51(4): 622-645. 
Laing, M., 't Hart, P. (2011) Seeking and keeping the hot seat: A comparative analysis of party leader succession. In: P. 't Hart and J. Uhr (eds) How Power Changes Hands. Basingstoke: Palgrave, pp. 111-132

Lederman, L. (2007/8) Disney examined: A case study in corporate governance and CEO succession. New York Law School Review, 52(2): 557-582

Leduc, L. (2001) Democratizing party leadership selection. Party Politics, 7(2): 323-41

Lees-Marshment, J. (2012) Political marketing and opinion leadership. In L. Helms (ed.) Comparative Political Leadership. Basingstoke: Palgrave, pp. 165-185.

Mair, P. (2013) Ruling the Void: The Hollowing of Western Democracy. London: Verso.

McCauley, M., Carter, S. (eds)(1986) Leadership and Succession in the Soviet Union, Eastern Europe and China. London: MacMillan.

Minkin, Lewis (2014) The Blair Supremacy: A Study in the Politics of Labour's Party Management. Manchester: Manchester University Press.

Mughan, A. (2015) Parties, conditionality and leader effects in parliamentary elections. Party Politics 21(1): 28-39.

Ocasio, W. (1994) Political dynamics and the circulation of power: CEO successions in U.S. industrial corporations, 1960-1990. Administrative Science Quarterly 39(2): 285-212

Ocasio, W. (1999) Institutionalised action and and corporate governance: The reliance on rules of CEO succession. Administrative Science Quarterly 44(2): 384-416

Ocasio, W., Kim, H. (1999) The circulation of corporate control. Administrative Science Quarterly 44(3): 532-562

Pilet, J-B., Cross, W. (eds)(2014), The Selection of Political Party Leaders in Contemporary Democracies. London: Routledge

Poulin, B.J., Hackman, M.Z., Barbarasa-Mihai, C. (2007) Leadership succession: The challenge to succeed and the vortex of failure. Leadership 3(3): 301-324

Punnett, R. M. (1992) Selecting the Party Leader: Britain in Comparative Perspective. London: Harvester Wheatsheaf

Quinn, T. (2005) 'Leasehold or freehold? Leader eviction rules in the British Conservative and Labour parties', Political Studies, 53(4), 793-815.

Rahat, G., Hazan, R. Y. (2001) Candidate selection methods: An analytical framework. Party Politics 7(3): 297-322. 
Renshon, S. (2000) Political leadership as social capital: Governing in a divided national culture. Political Psychology 21(1): 199-226.

Renshon, S. (2012) The contributions of political psychology to comparative political leadership analysis. In: L. Helms (ed.) Comparative Political Leadership. Basingstoke: Palgrave, pp. 186-206.

Rothwell, W.J. (2010) Effective Succession Planning: Ensuring Leadership Continuity and Building Talent From Within. New York: Amacom

Rowe, W. G., Cannella Jr., A. A., Rankin, D. and Gorman, D. (2005) Leader succession and organizational performance: Integrating the common-sense, ritual scapegoating, and vicious-circle succession theories. The Leadership Quarterly 16(2): 197-219

Russell, M. (2005) Building New Labour: The Politics of Party Organisation. Basingstoke: Palgrave.

Stark, L. (1996) Choosing a Leader: Party Leadership Contests in Britain from Macmillan to Blair. London: Macmillan

't Hart, P. (2014) Understanding Public Leadership. Houndmills: Palgrave

't Hart, P. and Uhr, J. (eds)(2011) How Power Changes Hands: Transition and Succession in Government. Houndmills: Palgrave

Teodoro, M. (2013) Moving in, managing up: Executive job formation and political behaviour. Journal of Public Policy 33(2): 137-164

Theakston, K., De Vries, J. (eds)(2012) Former Leaders in Modern Democracries: Political Sunsets. Basingstoke: Palgrave

Tiffen, R. (2015), Thinking of dumping a prime minister? History isn't encouraging. Inside Story 8 February 2015. http://insidestory.org.au/thinking-of-dumping-a-primeminister-history-isnt-encouraging, consulted 10 February 2015

Turner, J. C., Haslam, S. A. (2001) Social identity, organizations, and leadership. In M.E. Turner (ed.) Groups at work: Theory and research. Mahwah, N.J: Lawrence Erlbaum Associates, pp. 25-65.

Tushman, M.L., Rosenkopf, L. (1996) Executive succession, strategic reorientation and performance growth. Management Science 42(7): 939-953

Weller, P. (1983) The vulnerability of prime ministers: A comparative perspective. Parliamentary Affairs, 36(1): 96-117

Weller, P. (1994) Party rules and the dismissal of prime ministers: Comparative perspectives from Britain, Canada and Australia. Parliamentary Affairs, 47(2): 13343 
